\title{
PENGARUH PENAMBAHAN PROBIOTIK DENGAN DOSIS BERBEDA PADA PAKAN TERHADAP PERTUMBUHAN DAN RASIO KONVERSI PAKAN (FCR) IKAN NILA (Oreochromis niloticus)
}

\author{
Ahmad Fahrizal ${ }^{1}$, M. Nasir ${ }^{2}$ \\ 1) Staf Pengajar di Fakultas Perikanan Universitas Muhammadiyah Sorong \\ 2) Mahasiswa Fakultas Perikanan Universitas Muhammadiyah Sorong \\ Jl. Pendidikan KM. 8 Kota Sorong \\ Email: a.fahrizal.ab@gmail.com
}

\begin{abstract}
Abstrak.
Pengaruh Penambahan Probiotik Dengan Dosis Berbeda Pada Pakan Terhadap Pertumbuhan Dan Rasio Konversi Pakan (FCR) Ikan Nila (Oreochromis niloticus). Penelitian ini bertujuan Untuk mengetahui pengaruh penambahan probiotik dengan dosis berbeda pada pakan terhadap pertumbuhan ikan nila.Metode yang digunakan dalam penelitian ini adalah metode eksperimen dengan analisa data yang digunakan adalah Rancangan Acak Lengkap (RAL). Wadah yang digunakan dalam penelitian adalah ember yang berkapasitas 100 liter sebanyak 13 buah. Pada penelitian ini terdiri dari 3 perlakuan dan 1 kontrol. Masingmasing perlakuan 4 kali ulangan. Setiap wadah berisi ikan sebanyak 10 ekor. Dosis probiotik yang digunakan yaitu perlakuan I dengan dosis $5(\mathrm{ml})$, perlakuan II $10 \mathrm{ml}$, dan perlakuan III 15 ml.Nilai FCR yang diperoleh selama penelitian yaitu pada perlakukan I dengan pemberian probiotik dengan dosis $5 \mathrm{ml}$ diperoleh nilai FCR sebesar 1.82, perlakuan II dengan pemberian probiotik dengan dosis $10 \mathrm{ml}$ diperoleh nilai FCR sebesar 1.75 dan perlakuan III dengan pemberian probiotik dengan dosis probiotik $15 \mathrm{ml}$ diperoleh nilai FCR sebesar 1.73. Kesimpulan dari penelitian ini yaitu dengan penambahan probiotik dengan dosis berbeda pada pakan tidak memberikan pengaruh secara signifikan terhadap pertumbuhan ikan nila berdasarkan hasil uji dari analisis sidik ragam anova. Pemberian probiotik lebih perpengaruh terhadap FCR ikan nila. Nilai Konversi pakan yang terbaik dari ketiga perlakuan yang dilakukan selama penelitian terdapat pada perlakuan III $(15 \mathrm{ml})$ dimana nilai FCR nya sebesar 1.73 . Dengan ini menunjukan bahwa setiap pemberian pakan sebanyak $1.73 \mathrm{~kg}$ menghasilkan berat ikan sebesar $1 \mathrm{~kg}$. Sedangkan nilai SR diperoleh $100 \%$ artinya bahwa selama penelitian ini berlangsung tidak mengalami kematian pada biota yang diteliti.
\end{abstract}

Kata Kunci : Pengaruh probiotik, pertumbuhan, FCR.

\section{PENDAHULUAN}

Ikan Nila (Oreochromis niloticus) merupakan hasil persilangan dan seleksi jenis-jenis nila dari Taiwan, Mesir, Thailand, Ghana, Singapura, Israel, Senegal, dan Kenya. Jenis ini dikembangkan pertama kali oleh International Center for Living Aquatic Research Management (ICLARM) di Filipina pada tahun 1987. Program tersebut dibiayai oleh Asian Development Bank (ADB) dan United Nations Development Programme (UNDP).

Ikan nila merupakan salah satu jenis ikan air tawar yang populer di kalangan masyarakat. Oleh karena kepopulerannya membuat ikan nila memiliki prospek usaha yang cukup menjanjikan. Apabila ditinjau dari segi pertumbuhan, ikan nila merupakan jenis ikan yang memiliki laju pertumbuhan yang cepat dan dapat mencapai bobot tubuh yang jauh besar dengan tingkat produktivitas yang cukup tinggi.

Faktor lain yang memegang peranan penting atas prospek ikan nila adalah rasa dagingnya yang khas, warna dagingnya yang putih bersih dan tidak berduri dengan kandungan gizi yang cukup tinggi, sehingga sering dijadikan sebagai sumber protein yang murah dan mudah didapat, serta memiliki harga jual yang terjangkau oleh masyarakat. Prospek pengembangan budidaya ikan nila juga diperkirakan memiliki peluang yang sama baiknya dengan pengembangan jenis ikan konsumsi 
lainnya, karena ikan nila produktif apabila dipelihara di berbagai lahan, bukan hanya di kolam air tawar, tetapi juga dipelihara di tambak-tambak air payau. Hal ini karena ikan nila memiliki batasan toleransi yang cukup tinggi terhadap berbagai kondisi lingkungan perairan. Ikan nila yang masih berukuran kecil pada umumnya lebih tahan terhadap perubahan lingkungan, dibandingkan dengan ikan nila yang berukuran besar (Khairuman dan Amri, 2003).

Kabupaten Sorong merupakan daerah yang memiliki potensi sumberdaya alam yang besar baik di daratan maupun di lautan. Sebagian besar potensi yang ada tersebut belum banyak dioptimalkan dan dikelola secara baik. Salah satu potensi yang dimilikia adalah lokasi budidaya yang masih sangat potensial untuk dikembangkan terutama dalam budidaya ikan nila, seperti dibeberapa kelompok pembudidaya yang ada di Distrik Aimasmelakukan kegiatan budidaya ikan nila.

Permasalahan yang dialami para pembudidaya adalah harga pakan yang sangat mahal. Oleh karena itu, perlu diambil langkah guna menekan biaya pakan yang dapat menunjang efisiensi pakan dengan pola pemberian pakan yang tidak berlebihan, menggunakan pakan tambahan alternatif yang lebih murah serta menerapkan teknologi yang tepat dapat mengurangi kebutuhan pakan ikan. Berdasarkan data tersebut di atas maka penulis mengambil judul penelitian tentang : Pengaruh Penambahan Probiotik Dengan Dosis Berbeda Pada Pakan Terhadap Pertumbuhan Dan Rasio Konversi Pakan (FCR) Ikan Nila (Oreochromis niloticus).

\section{METODE}

Metode yang digunakan dalam penelitian ini adalah metode eksperimen yaitu melakukan percobaan dan pengamatan langsung dengan mengalami atau membuktikan sendiri sesuatu yang diteliti/dipelajari. Menurut Arboleda (1981:27), mendefinisikan eksperimen sebagai suatu penelitian yang dengan sengaja meneliti melakukan manipulasi terhadap satu atau lebih variabel dengan suatu cara tertentu sehingga berpengaruh pada satu atau lebih variabel lain yang diukur. Selain itu Gay (1981:207-208) menyatakan bahwa metode penelitian eksperimental merupakan satu-satunya metode penelitia yang dapat menguji secara benar hipotesis yang menyangkut hubungan kasual (sebab akibat). Dalam penelitian eksperimen dilakukan manipulasi paling sedikit satu variabel, mengontrol variabel lain yang relevan dan mengobservasi efek atau pengaruhnya terhadap satu atau lebih variabel tersebut.

\section{Prosedur Pengumpulan Data}

Prosedur penelitian yang dilakukan pada kegiatan penelitian ini adalah disiapkan wadah dan peralatan 1 hari sebelum melaksanakan kegiatan penelitian serta dibersihkan agar terkondisikan steril dari penyakit. Persiapan biota percobaan yaitu benih ikan nila dengan jumlah dan ukuran yang yang telah ditentukan yaitu 10 ekor benih setiap wadah(ember) dengan ukuran masing-masing antara $8-10 \mathrm{~cm}$ dan beserta pakan ikannya.

Pada pengukuran kualitas air harian yang akan diukur adalah $\mathrm{pH}$, suhu, dan DO. Pengukuran dilakukan pada pagi hari antara pukul 07.00-07.30 WIT dan pengukuran pada sore hari antar pukul 16.00-16.30 WIT. Pengukuran $\mathrm{pH}$ dilakukan dengan menggunakan $\mathrm{pH}$ meter, pada suhu dilakukan pengukuran dengan menggunakan thermometer suhu, dan pada DO dilakukan dengan pengukuran menggunakan DO meter. Setelah dilakukan pengukuran, dicatat pada tabel data hasil pengamatan.

Pada pemberian pakan dilakukan perhitungan berat ikan terlebih dahulu, setelah itu dilakukan penimbangan berat pakan yang dibutuhkan dengan cara perhitungan yaitu 5\% dari berat tubuh ikan. Sedangkan jumlah pemberian probiotik yang digunakan dilakukan dengan dosis yang berbeda yaitu perlakuan I dengan dosis 5(ml), perlakuan II $10 \mathrm{ml}$, dan perlakuan III $15 \mathrm{ml}$ dan dicampurkan dengan jumlah pakan. Pemberian pakan dilakukan pada pagi hari antara pukul 
Tabel 1.Komposisi Pakan

\begin{tabular}{|l|l|l|l|l|}
\hline \multicolumn{1}{|c|}{ Waktu } & \multicolumn{1}{|c|}{ Dosis } & Frekuensi & \multicolumn{1}{|c|}{$\begin{array}{c}\text { Jenis } \\
\text { pakan }\end{array}$} & Mutu/komposisi pakan \\
\hline - Pagi hari pukul & $5 \%$ dari & $2 \times$ xehari & Pakan buatan & Protein kasar 35\% \\
$\begin{array}{l}\text { 08.00-08.30 } \\
\text { berat tubuh }\end{array}$ & & & Lemak kasar 2\% \\
- Sore hari pukul \\
$\begin{array}{l}\text { ikan } \\
\text { ik.30-17.00 }\end{array}$ & & & $\begin{array}{l}\text { Serat kasar 3\% } \\
\text { Abu kasar 13\% } \\
\text { Kadar air 12\% }\end{array}$ \\
\hline
\end{tabular}

Sumber : Daftar Label Pakan Merk FF 999

\section{Teknik Analisis Data}

Analisa data yang digunakan dalam penelitian ini adalah Rancangan Acak Lengkap (RAL). Rancangan Acak Lengkap merupakan rancangan yang paling sederhana , cocok untuk materi yang bersifat homogen yang artinya variasi diantaranya relative kecil. Rancangan Acak Lengkap tidak memiliki lokal control, sehingga cocok digunakan untuk kondisi lingkungan, alat, bahan dan media yang homogen seperti laboratorium, rumah kaca atau ruang-ruang terkontrol lainnya (Hanafiah, 1991).

Rancangan Acak Lengkap (RAL) tersebut terdiri dari 3 perlakuan dengan masing-masing 4 kali ulangan. Adapun perlakuan tersebut adalah :

- Perlakuan A : Pemeliharaan ikan nila dengan penambahan probiotik $5 \mathrm{ml}$ dari jumlah pakan yang digunakan.

- Perlakuan B : Pemeliharaan ikan nila dengan penambahan probiotik $10 \mathrm{ml}$ dari jumlah pakan yang digunakan.

- Perlakuan C : Pemeliharaan ikan nila dengan penambahan probiotik $15 \mathrm{ml}$ dari jumlah pakan yang digunakan.

Data yang diperoleh selanjutnya dianalisis sidik ragam (ANOVA) untuk mengetahui pengaruh perlakuan yang diberikan terhadap pertumbuhan dan kelangsungan hidup ikan.

\section{a. Peubah yang Diamati}

Pada penelitian ini akan diamati pertumbuhan, perbandingan jumlah pakan yang dihabiskan selama pemeliharaan dengan jumlah berat total ikan yang dihasilkan (FCR) dan tingkat kelangsungan hidup (SR).

\section{Perhitungan Pertumbuhan}

\section{- Pertumbuhan Berat Muntlak}

Menurut (Effendi, 2004) pertumbuhan berat mutlak dihitung dengan rumus sebagai berikut :

$$
\text { Rumus : W = Wt - Wo }
$$

Keterangan Rumus :

W : Pertumbuhan berat muntlak

Wt : Berat akhir ikan (g)

Wo : Berat awal ikan (g).

\section{- Laju Pertumbuhan Spesifik}

Laju pertumbuhan spesifik diukur setiap minggu pertama hingga minggu akhir penelitian. Laju pertumbuhan ini dihitung dengan menggunakan rumus Specific Growth Rate (SGR). Menurut (Huisman, 1976) dengan rumus sebagai berikut :

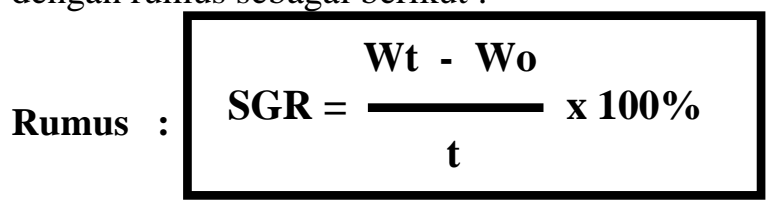

Keterangan Rumus :

SGR : Laju pertumbuhan mingguan (\%)

Wt : Bobot rata-rata ikan pada waktu $\mathbf{t}(\mathrm{g})$

Wo : Bobot rata-rata ikan pada waktu awal penelitian (g)

$\mathrm{t} \quad$ : Waktu penimbangan (hari). 


\section{Perhitungan FCR (Feed Convertion Rate)}

Menurut Djarijah (2004)untuk menghitung efisiensi penggunaan pakan dapat digunakan rumus sebagai berikut :

Rumus :

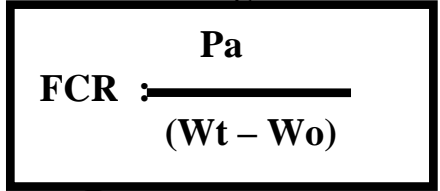

Keterangan Rumus :

FCR : Feed Convertion Ratio

$\mathrm{Pa} \quad$ : Jumlah pakan yang

dikomsumsi

Wt : Biomassa ikan akhir $(\mathrm{kg})$

Wo : Biomassa ikan awal $(\mathrm{kg})$

\section{Tingkat Kelangsungan Hidup /}

\section{Survival Rate (SR)}

Untuk mengetahui nilai SR digunakan rumus sederhana yaitu jumlah ikan yang hidup dibagi dengan jumlah ikan tebar awal dikali dengan seratus persen (Baktiar, 2006).
Rumus : $\quad \mathrm{SR}=\frac{\mathrm{Nt}}{\mathrm{No}} \times 100 \%$

Keterangan Rumus :

SR : Tingkat kelangsungan hidup (\%)

$\mathrm{Nt}$ : Jumlah populasi ikan akhir (ekor)

No : Jumlah populasi ikan awal (ekor)

\section{HASIL DAN PEMBAHASAN PENELITIAN}

1. Gambaran Hasil Pengolahan Data

Pengukuran pertumbuhan berat dilakukan satu kali seminggu dan selama penelitian pengukuran berat dilakukan sebanyak 5 yaitu pengukuran pada berat awal dan sampai pada minggu ke empat. Hasil pertumbuhan berat ikan nila dianalisis dengan dengan analisis sidik ragam anova.Adapun hasil pengukuran berat selama penelitian adalah sebagai berikut :

Tabel 2. Laju Pertumbuhan Berat Ikan Nila

\begin{tabular}{|c|c|c|c|c|c|c|}
\hline \multirow{2}{*}{$\begin{array}{l}\text { Kosentrasi probiotik } \\
(\mathrm{ml})\end{array}$} & \multicolumn{4}{|c|}{ Ulangan } & \multirow[b]{2}{*}{ Jumlah } & \multirow[b]{2}{*}{ Rerata } \\
\hline & 1 & 2 & 3 & 4 & & \\
\hline $5 \mathrm{ml}$ & 436 & 434 & 435 & 438 & 1.743 & 435.75 \\
\hline $10 \mathrm{ml}$ & 462 & 461 & 462 & 459 & 1.844 & 461 \\
\hline $15 \mathrm{ml}$ & 512 & 508 & 510 & 502 & 2.032 & 508 \\
\hline Jumlah & 1.410 & 1.403 & 1.407 & 1.399 & 5619 & 1.404 .75 \\
\hline
\end{tabular}

Tabel 3. Hasil Perhitungan Anova

\begin{tabular}{|l|r|r|r|r|r|c|}
\hline \multicolumn{1}{c|}{$\begin{array}{c}\text { Sumber } \\
\text { Variasi }\end{array}$} & \multicolumn{1}{c|}{$J K$} & \multicolumn{1}{c|}{$d b$} & \multicolumn{1}{c|}{ KT } & F Hitung & P-value & F Tabel \\
\hline Antara Kelompok & 32438 & 2 & 16219 & 0.032713682 & 0.96793 & 4.256495 \\
\hline Dalam Kelompok & 4462078 & 9 & 495786.4444 & & & \\
\hline & & & & & & \\
\hline Total & 4494516 & 11 & & & & \\
\hline
\end{tabular}




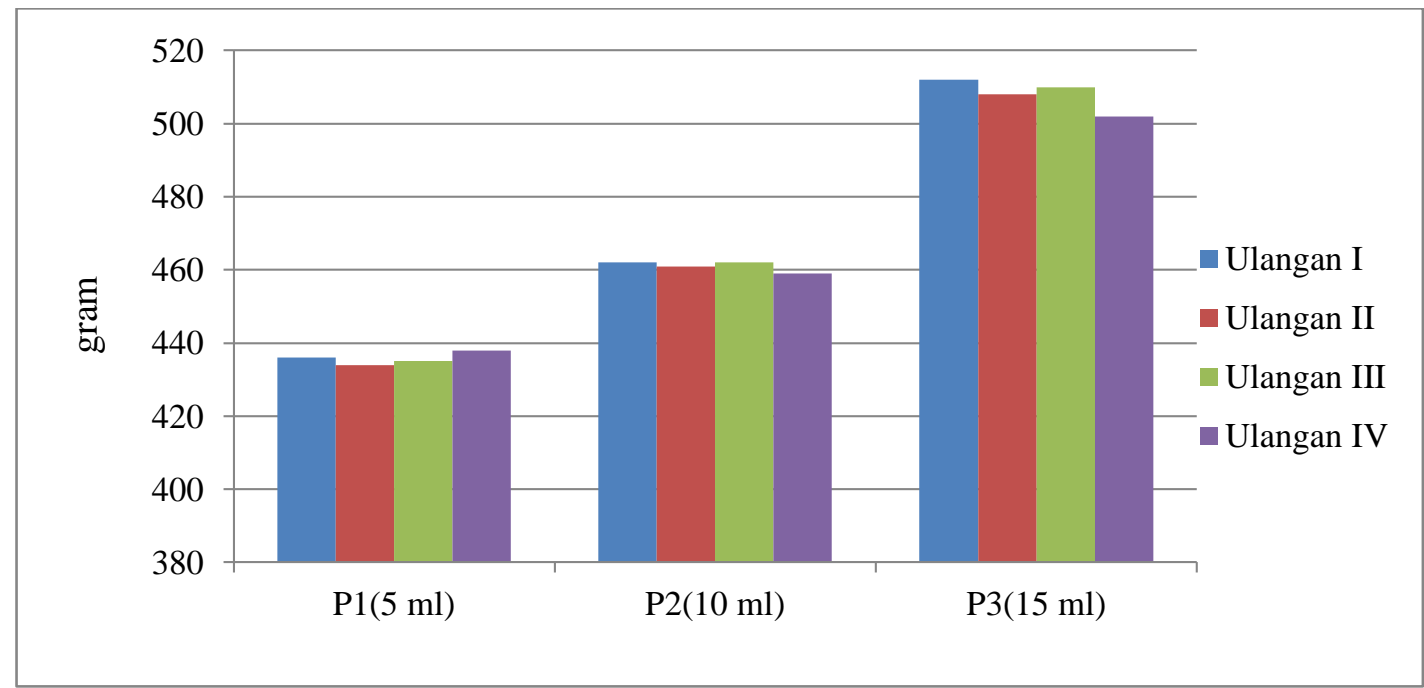

Gambar1. Grafik Pertumbuhan Berat Ikan Nila

\section{Pertumbuhan Panjang}

Selain pengukuran pertumbuhan berat, pengukuran pertumbuhan panjang pun dilakukan pada penelitian ini dengan motode analisis statistik yang sama yaitu analisis sidik ragam anova. Adapun hasil pengukuran panjang yang didapatkan selama penelitian dapat dilihat pada Tabel berikut.

Tabel 4. Laju Pertumbuhan Panjang Ikan Nila

\begin{tabular}{|c|c|c|c|c|c|c|}
\hline \multirow{2}{*}{$\begin{array}{c}\text { Kosentrasi probiotik } \\
(\mathrm{ml})\end{array}$} & \multicolumn{5}{|c|}{ Ulangan } & \multirow{2}{*}{ Rerata } \\
\cline { 2 - 6 } & & 2 & 3 & & Jumlah & R \\
\hline $5 \mathrm{ml}$ & 19.8 & 20 & 19.5 & 19.9 & 79.2 & 19.8 \\
\hline $10 \mathrm{ml}$ & 19.6 & 19.19 & 19.9 & 20 & 78.69 & 19.6725 \\
\hline $15 \mathrm{ml}$ & 20.1 & 19.8 & 20 & 19.8 & 79.7 & 19.925 \\
\hline Jumlah & & & & & & \\
\hline
\end{tabular}

Tabel 5. Hasil Hitungan Anova

\begin{tabular}{|c|c|c|c|c|c|c|}
\hline $\begin{array}{l}\text { Sumber } \\
\text { Variasi }\end{array}$ & $J K$ & $D b$ & $K T$ & F Hitung & $P$-value & F Tabel \\
\hline Antara Kelompok & 0.2894 & 2 & 0.1447 & $\begin{array}{r}0.00016397 \\
6\end{array}$ & $\begin{array}{r}0.99983 \\
6\end{array}$ & $\begin{array}{r}4.25649 \\
5\end{array}$ \\
\hline Dalam Kelompok & $\begin{array}{r}7942.007 \\
6\end{array}$ & 9 & $\begin{array}{r}882.445288 \\
9\end{array}$ & & & \\
\hline Total & 7942.297 & 11 & & & & \\
\hline
\end{tabular}




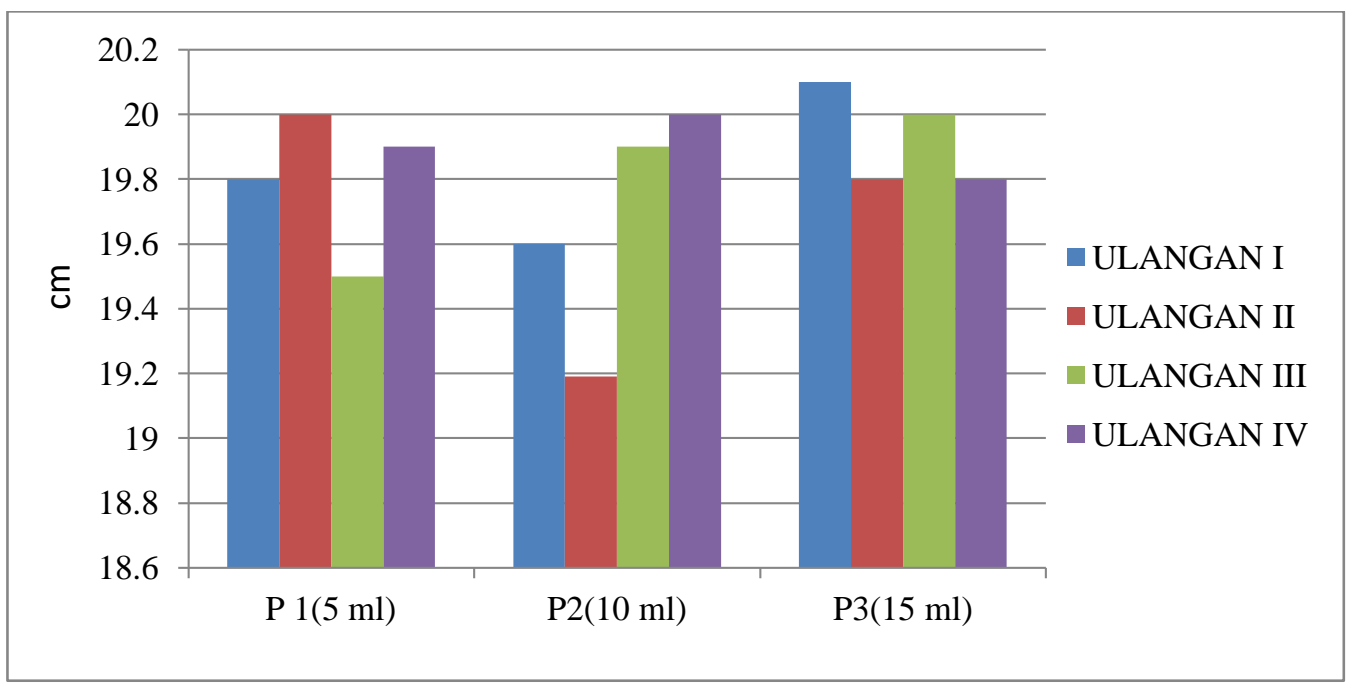

Gambar 2. Grafik Pertumbuhan Panjang Ikan Nila

Dari Grafik di atas dapat dilihat bahwa pengaruh pemberian probiotik terhadap pertumbuhan berat dan panjang ikan nila tidak memiliki pengaruh secara siknifikan sebagaimana berdasarkan dari hasil uji sidik ragam anova menunjukkan bahwa secara statistik nilai ketiga perlakuan tidak berbeda secara siknifikan dimana nilai $\mathrm{f}$ tabel lebih besar daripada nilai $\mathrm{f}$ hitung yang menandakan bahwa ketiga perlakuan memiliki notasi yang sama. Sehingga tidak perlu melakukan uji statistic atau uji lanjutan seperti uji BNt karena nilai f hitung lebih rendah daripada $f$ tabel. Sebagaimana pengalaman yang diungkapkan oleh Gomes dan Gomes (1984) dalam buku Kemas Ali Hanafiah bahwa uji BNt akan dilakukan apabila nilai $f$ hitung lebih tinggi daripada $f$ tabel.

\section{Kelangsungan Hidup atau Survival Rate (SR)}

Tingkat kelangsungan hidup atau survival rate (SR) ikan adalah presentase jumlah ikan yang hidup pada saat waktu tertentu dibandingkan dengan jumlah ikan pada awal pemeliharaan. Untuk mengetahuinya digunakan rumus sederhana yaitu jumlah ikan yang hidup dibagi dengan jumlah ikan tebar awal dikali dengan seratus persen (Baktiar, 2006).

Selama melakukan penelitian diperoleh hasil kelangsungan hidup 100\% yang artinya bahwa biota yang dijadikan objek penelitian tidak mengalami kematian selama penelitian berlangsung. Hasil ini diperoleh tidak terlepas dari persiapan wadah yang baik, penggunaan pakan dengan kandungan gizi yang baik, serta pengontrolan kualitas air yang teratur.

$$
\text { Untuk }
$$

mempertahankan

kelangsungan hidup dan pertumbuhan ikan, maka diperlukan makanan yang memenuhi nutrisi ikan. Factor yang mempengaruhi kelangsungan hidup ikan adalah padat tebar, pemberian pakan, penyakit dan kualitas air yang meliputi suhu, kadar amoniak dan nitrit, oksigen terlarut, $\mathrm{pH}$ perairan. Nilai tingkat kelangsungan hidup ikan yang baik rata-rata 63,5 - 86,0 (DEPTAN, 1999).

\section{Rasio Konversi Pakan atau Feed Conversion Ratio (FCR)}

Konversi pakan atau Feed Conversion Ratio (FCR) dan efesiensi pakan merupakan indicator untuk menentukan efektifitas pakan. Konversi pakan dapat diartikan sebagai kemampuan spesies akuakultur mengubah pakan menjadi daging sedangkan efesiensi pakan adalah bobot basah daging ikan yang diperoleh per satuan berat kering pakan yang diberikan (Watanabe, 1988). Nilai konversi pakan menunjukan bahwa sejauh mana makanan efesien dimanfaatkan oleh ikan peliharaan. Oksigen secara tidak langsung mempengaruhi besar kecilnya konversi pakan (Soetomo, 1987).Nilai FCR yang dihasilkan selama penelitian dari tiga 


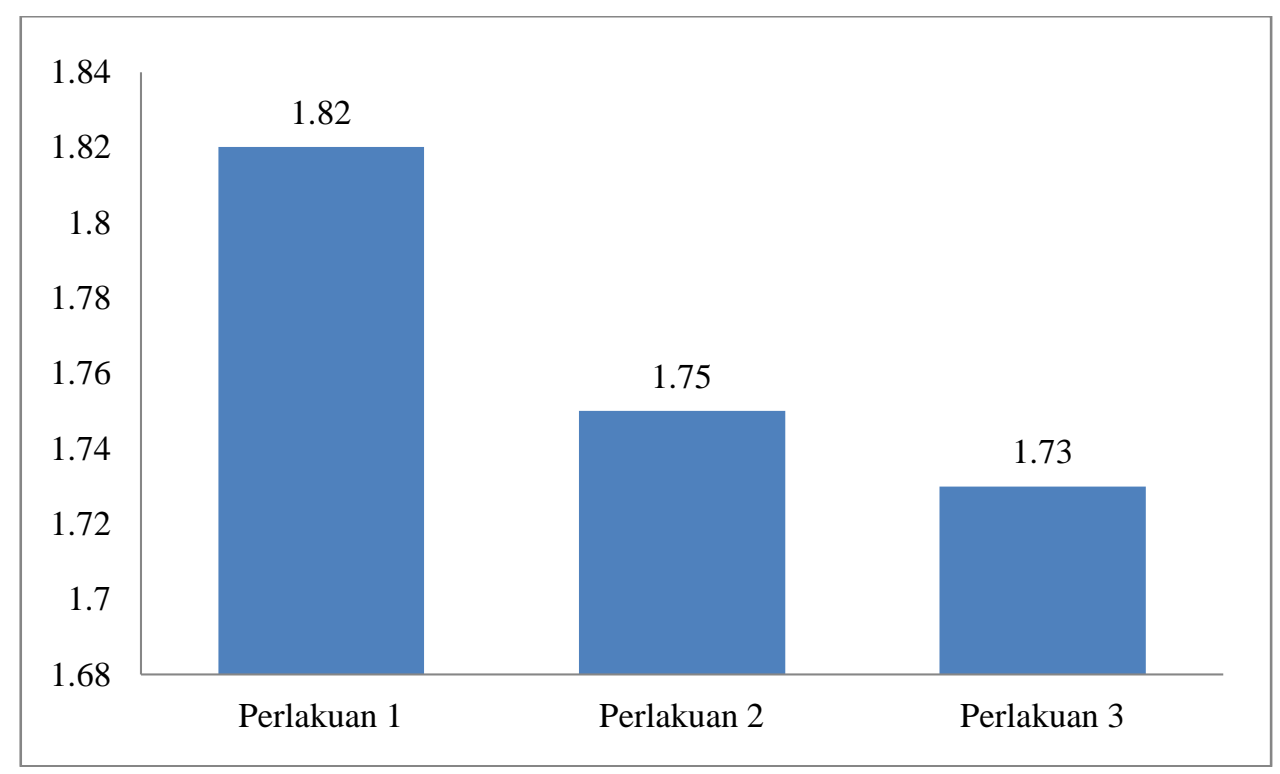

Gambar 3. Grafik Nilai FCR

Dilihat dari Grafik di atas bahwa pemberian probiotik dengan dosis $5 \mathrm{ml}$ diperoleh nilai FCR sebesar 1.82, pemberian probiotik dengan dosis $10 \mathrm{ml}$ diperoleh nilai FCR sebesar 1.75 dan pemberian probiotik dengan dosis $15 \mathrm{ml}$ diperoleh nilai FCR sebesar 1.73. Dengan hasil ini dapat diketahui bahwa nilai FCR yang terbaik terjadi pada perlakuan ketiga dengan pemberian dosis probiotik sebesar $15 \mathrm{ml}$ yang diperoleh nilai FCR 1.73. Dengan ini menunjukkan bahwa setiap pemberian pakan sebanyak $1.73 \mathrm{~kg}$ menghasilkan berat ikan sebesar $1 \mathrm{~kg}$.

Menurut (Rika Putri) dengan penggunaan probiotik pembudidaya ikan dapat bisa menekan FCR dalam penggunaan pakan komersial hingga $0.8 \mathrm{~kg}$ untuk menghasilkan $1 \mathrm{~kg}$ ikan. Selain itu penggunaan probiotik juga bisa mempercepat waktu pemeliharaan.

Hal ini menunjukan FCR yang efesien sebagaimana dikemukakan oleh (Effendy, 2004), semakin besar nilai FCR, maka semakin banyak pakan yang dibutuhkan untuk memproduksi $1 \mathrm{~kg}$ daging ikan. Nilai FCR ikan berkisar 1,5 2,5 .

\section{Efisiensi Pemberian Pakan}

Efisiensi pakan adalah bobot basah daging ikan yang diperoleh per satuan berat kering pakan yang diberikan atau merupakan presentase dari berat ikan yang dihasilkan dibandingkan dengan berat pakan yang diberikan. Hal ini sangat berguna untuk membandingkan nilai pakan yang mendukung pertambahan bobot. Efisien pakan berubah sejalan dengan tingkat pemberian pakan dan ukuran ikan. Efisiensi pakan dipengaruhi oleh beberapa factor diantaranya kualitas pakan, jumlah pakan, spesies ikan, ukuran ikan dan kualitas air. Adapun nilai efisiensi pemberian pakan yang didapatkan pada penelitian ini disajikan pada Gambar berikut. 


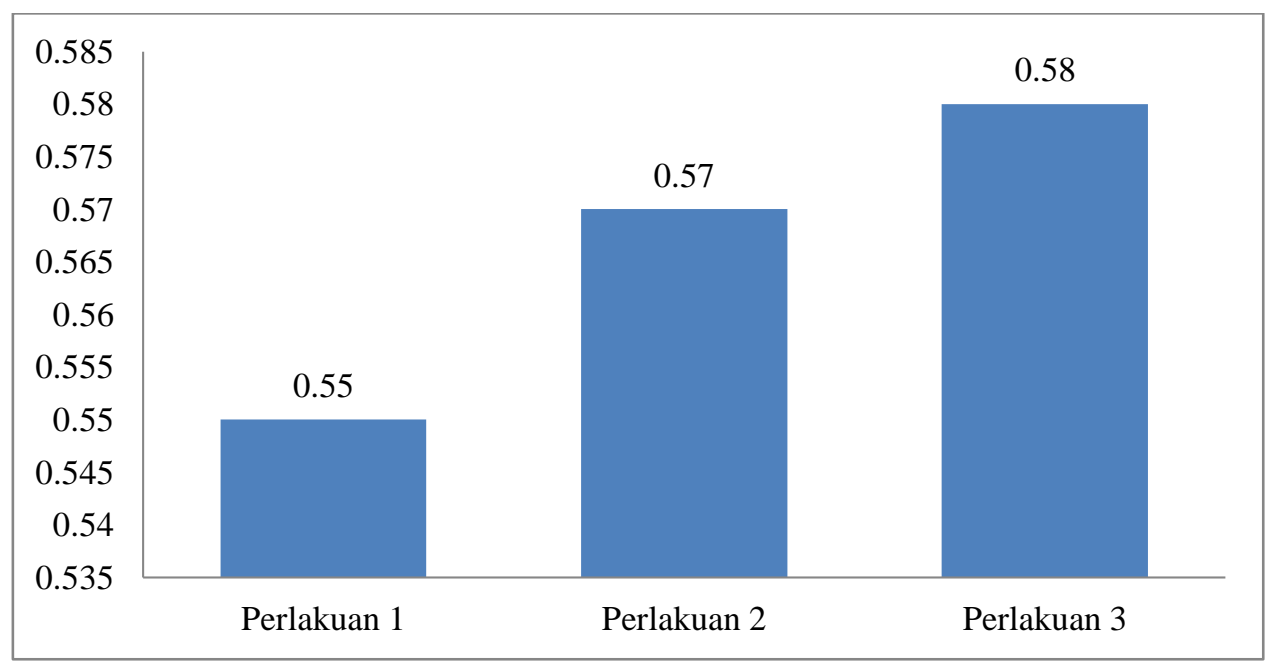

Gambar 4. Grafik Nilai Efisiensi Pakan

Dilihat dari grafik di atas bahwa pemberian probiotik dengan dosis $5 \mathrm{ml}$ diperoleh nilai EPP sebesar 55\%, pemberian probiotik dengan dosis $10 \mathrm{ml}$ diperoleh nilai EPP sebesar 57\% dan pemberian probiotik dengan dosis $15 \mathrm{ml}$ diperoleh nilai EPP sebesar 58\%. Dengan hasil ini dapat diketahui bahwa nilai EPP yang terbaik terjadi pada perlakuan ketiga dengan pemberian dosis probiotik sebesar $15 \mathrm{ml}$ yang diperoleh nilai EPP 58\%. Dengan ini menunjukkan bahwa setiap pemberian pakan sebanyak $1 \mathrm{~kg}$ dan yang berubah menjadi daging sebesar $0.58 \mathrm{~kg}$. Hal ini menunjukkan nilai efisien pakan yang baik sebagaimana dikaitkan dengan pernyataan Dirjen Perikanan (1985) menginformasikan bahwa pakan yang baik disyaratkan agar mempunyai nilai efisiensi pakan lebih dari $25 \%$.

\section{Manajemen Kualitas Air \\ 1. Suhu}

Suhu mempengaruhi pertumbuhan dan kelangsungan hidup. Hal ini karena suhu berpengaruh terhadap metabolisme, kadar oksigen, dan reaksi kimia dalam perairan.Suhu air mempunyai pengaruh yang besar terhadap proses pertukaran zat atau metabolisme dari makhluk-makhluk hidup. Selain itu juga suhu berpengaruh terhadap kadar oksigen terlarut, dimana semakin tinggi suhu suatu perairan maka semakin cepat pula perairan tersebut mengalami kejenuhan akan oksigen (Asmawi, 1983).Hasil suhu yang didapatkan selama penelitian dapat dilihat pada Gambar berikut. 


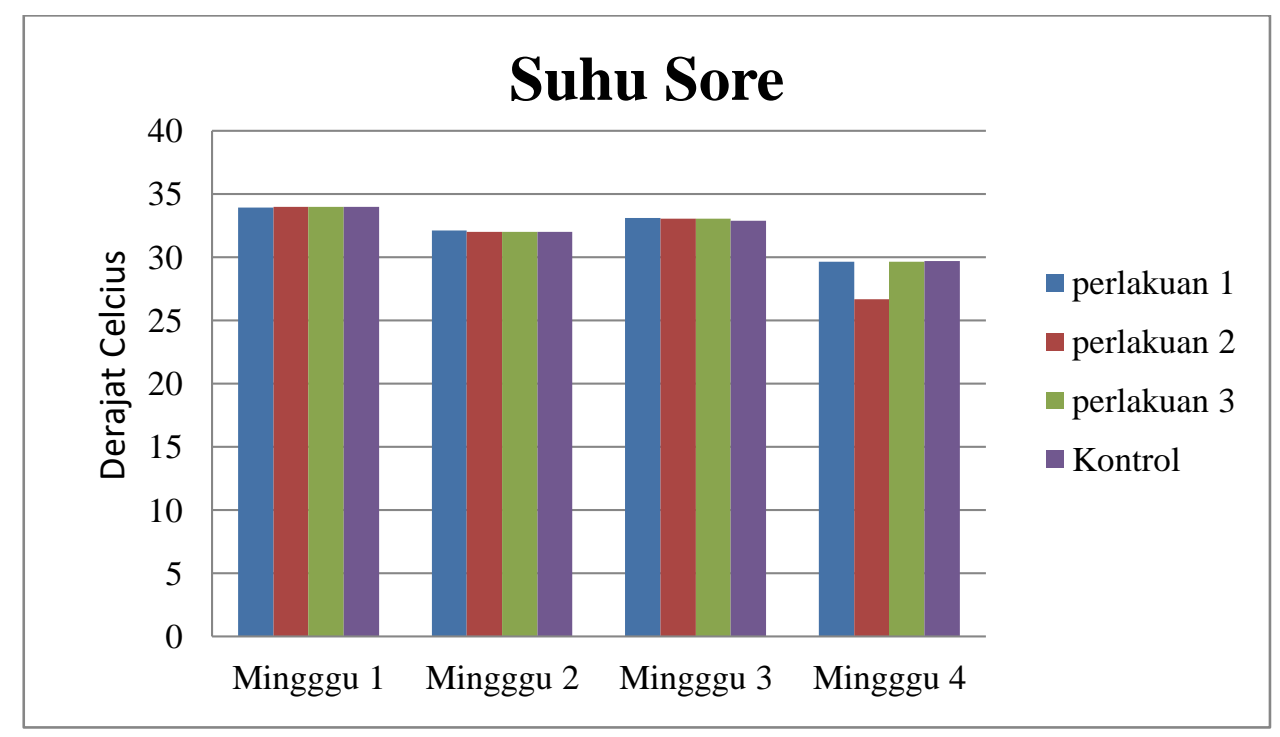

Gambar 5. Grafik Nilai Pengukuran Suhu di Pagi Hari

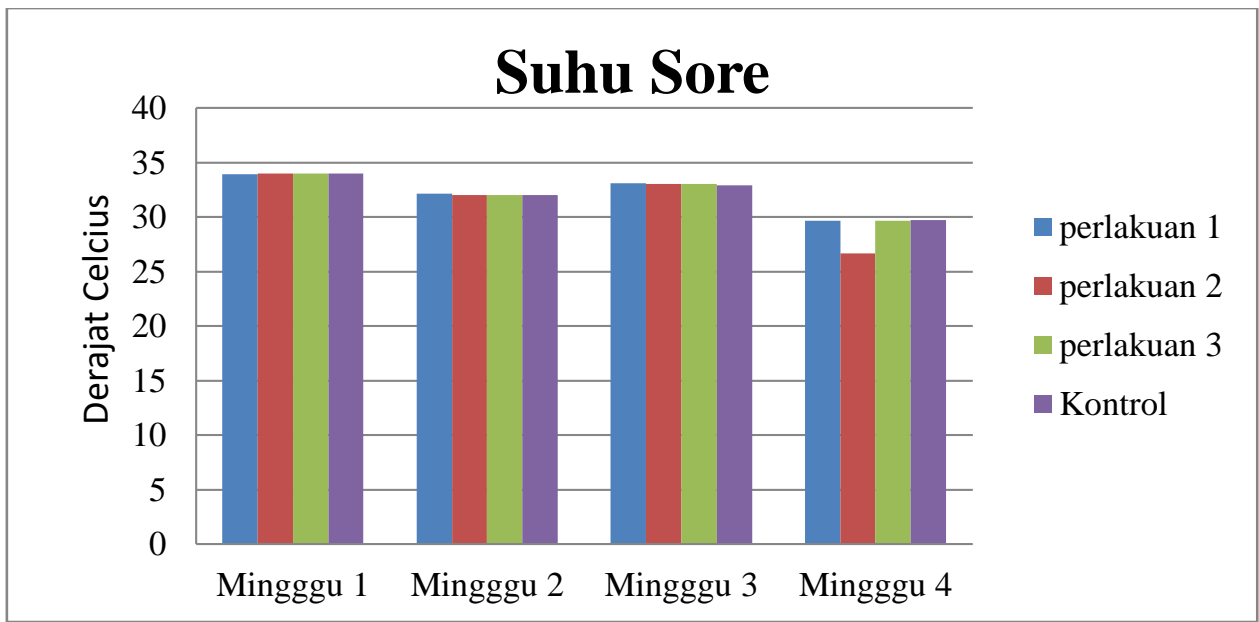

Gambar 6. Grafik Nilai Suhu Sore Hari

Dari gambar di atas pengukuran suhu yang dilakukan selama penelitian diperoleh hasil yaitu berkisar antara $26,9^{0}-34^{0} \mathrm{c}$. Suhu tertinggi rata-rata didapatkan pada minggu 1. Perbedaan suhu yang didapatkan yang sering mengalami perubahan karena adanya perbadaan cuaca yang sering terjadi di tempat penelitian.

\section{Derajat Keasaman atau $\mathrm{pH}$}

Derajat keasaman $(\mathrm{pH})$ adalah ukuran konsentrasi ion hydrogen yang menunjukkan suasana asam atau basa suatu perairan. Faktor yang mempengaruhi $\mathrm{pH}$ adalah konsentrasi karbondioksida dan senyawa yang bersifat asam. Nilai $\mathrm{pH}$ kurang dari 7 menunjukkan lingkungan yang masam, nilai $\mathrm{pH}$ di atas 7 menunjukkan lingkungan yang basa (alkalin) sedangkan $\mathrm{pH}$ sama dengan 7 menunjukkan keadaan lingkungan yang netral (Lesmana, 2004). Nilai pH yang diperoleh selama penelitian disajikan pada Gambar berikut. 


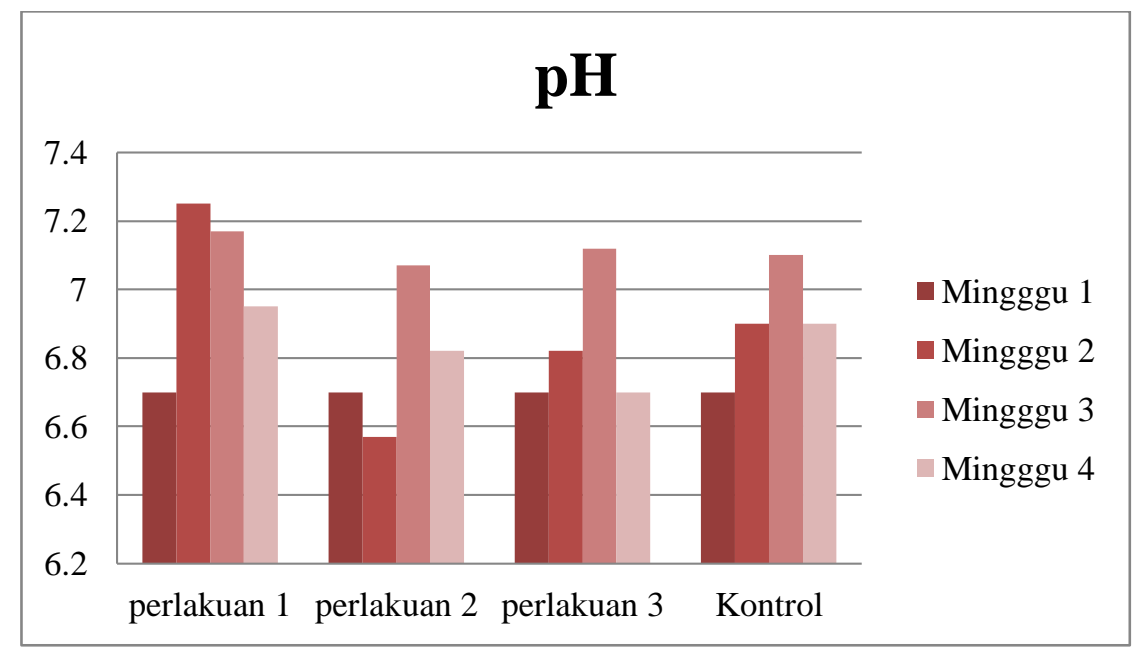

Gambar 7. Grafik Nilai pH Air

Dari hasil pengukuran selama penelitian diatas menunjukkan hasil $\mathrm{pH}$ berkisar antara 6.7-7.2. nilai tertinggi didapatkan pada minggu ke dua pada perlakuan pertama sebesar 7.2. Dari hasil pengukuran $\mathrm{pH}$ yang didapatkan dapat dikategorikan sebagai $\mathrm{pH}$ yang optimal yang baik bagi kegiatan budidaya ikan nila. Sebagai mana yang diungkapkan oleh Asmawi (1983), batas minimum pH yang ditoleransi ikan air tawar pada umumnya 4,0 dan batas maksim um 11,0. Menurut Soeseno (1971), pH yang terlalu rendah maupun yang terlalu tinggi terus menerus, dapat menyebabkan berkurangnya pertumbuhan pada ikan karena pada suasana tersebut mengganggu pertukaran zat di dalam tubuhnya.

\section{Oksigen Terlarut atau Dissolved Oksigen (DO)}

Dissolved Oksigen(DO) merupakan oksigen terlarut dalam perairan yang sangat diperlukan untuk proses respirasi baik plankton maupun ikan. Pengukuran oksigen dapat dilihat pada Grafik berikut.

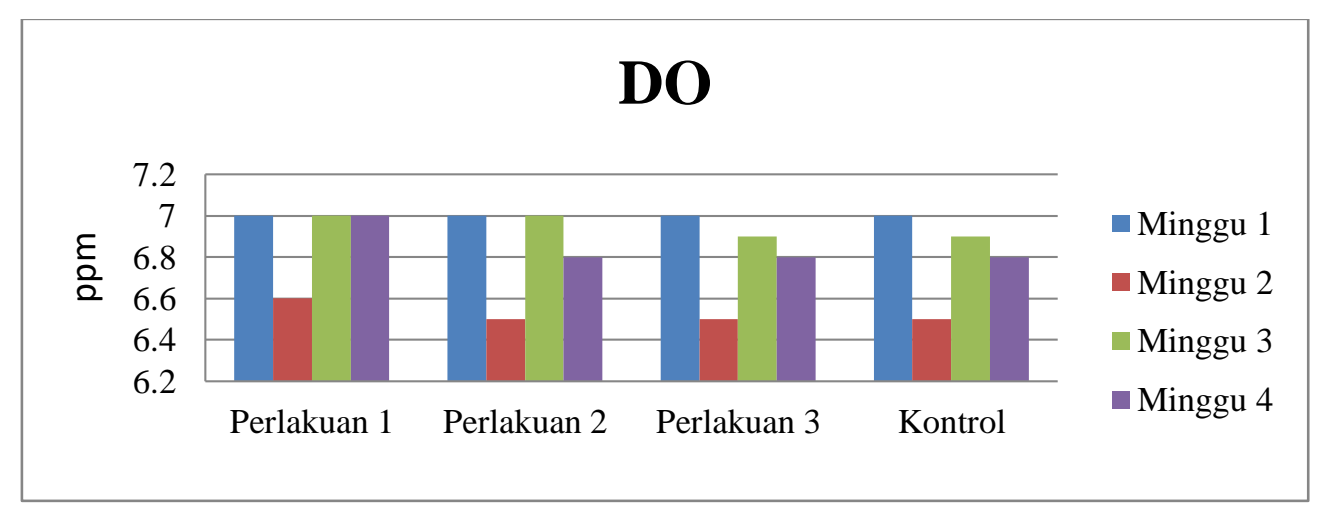

Gambar 8. Grafik Nilai DO

Dari Gambar grafik diatas menunjukkan bahwa hasil pengukuran DO berkisar antara 6.5-7 ppm. DO terendah didapatkan pada minggu kedua yang setiap pelakuan memiliki DO rata-rata $6.5 \mathrm{ppm}$ sedangkan pada minggu 1, 3, dan 4 memiliki kadar oksigen rata-rata 7 ppm.Dari hasil pengukuran DO yang mengalami perubahan yang terjadi selama penelitian disebabkan beberapa faktor yaitu jika terjadi kekeruhan yang disebabkan oleh sisa sisa makanan dan kotoran ikan dan jika terjadi mati lampu sehingga aerator tidak berfungsi untuk menyuplei oksigen. Namun variasi perubahan DO yang terjadi dalam hal penelitian ini sangat kecil sehingga tidak menganggu kehidupan ikan. 
Kadar oksigen terlarut dan pengaruhnya terhadap kelangsungan hidup ikan di dalam Efendi (2003) sebagai berikut

- $\quad<0.3$ hanya sedikit ikan yang bertahan.

- 0.3-1.0 akan mengakibatkan kematian ikan jika berlangsung lama.

- 1-5 ikan akan hidup pada kisaran ini tetapi pertumbuhannya lambat jika berlangsung lama.

- > 5 pada kisaran ini hampir semua organisme akuatik menyukainya.

\section{SIMPULAN}

Dari hasil penelitian yang dilakukan dapat ditarik kesimpulan bahwa dengan penambahan probiotik dengan dosis berbeda pada pakan tidak memberikan pengaruh secara signifikan terhadap pertumbuhan ikan nila berdasarkan hasil uji dari analisis sidik ragam anova. Pemberian probiotik lebih berpengaruh terhadap FCR ikan nila.Nilai Konversi pakan yang terbaik dari ketiga perlakuan yang dilakukan selama penelitian terdapat pada perlakuan ketiga dimana nilai FCR nya sebesar 1.73. Dengan ini menunjukan bahwa setiap pemberian pakan sebanyak $1.73 \mathrm{~kg}$ menghasilkan berat ikan sebesar $1 \mathrm{~kg}$.

\section{DAFTAR PUSTAKA}

Arboleda, C. R. 1981. Communications Ressearch. Manila: CFA. www.eurekapendidikan.com/2015 /11/metode-penelitian- eksperimen.html?m=1. Diakses pada tanggal 20 Mei 2016.

Asmawi, S. 1983. Pemelioharan Ikan Dalam Keramba. PT. Gramedia. Jakarta.

www.agustyar.com/2015/04/kimiaair.html?=1. Diakses pada tanggal 21 Maret 2016.

Dirjen Perikanan. 1985. Spesifikasi Teknik Pakan Udang. Direktorat Jendral Perikanan . Direktorat Bina Produksi. Jakarta $20 \mathrm{Hal}$.

Djarijah, A. S. 1995. Nila Merah. Pembenihan dan Pembesaran Secara Intensif. Kanisius. Yogyakarta.

Effendi dan Hefni, 2003. Telaah Kualitas

Air. kanisius. Yogyakarta.

Effendi,I. 2004 pengantar akuakultur. Jakarta: penebar swadaya.

Gay, L. R. 1981. Educational Research: Competencies for Analysis and Application. London: PrenticeHall International (UK)Itd. www.eurekapendidikan.com/2015 /11/metode-penelitianeksperimen.html?m=1. Diakses pada tanggal 20 Mei 2016.

Hanifah K.A., 1991. Rancangan Percobaan Teori dan Aplikasi. PT. Raja Grafindo Persada, Jakarta.

Khairuman dan Amri K. 2003. Budidaya Ikan Nila Secara Intensif. Agromedia Pustaka, Jakarta.

Lesmana, D.S. 2004. Kualitas Air Untuk Ikan Hias Air Tawar. Penebar Swadaya Jakarta 